\title{
STRATEGI PENGENDALIAN IMPOR SALMON-TROUT UNTUK KONSUMSI PASAR DALAM NEGERI
}

\section{Salmon-Trout Import Control Strategies for Domestic Market Consumption}

\author{
*Tenny Apriliani dan Rismutia Hayu Deswati \\ Balai Besar Riset Sosial Ekonomi Kelautan dan Perikanan \\ Gedung BRSDM KP I Lt. 4, Jalan Pasir Putih Nomor 1 Ancol Timur, Jakarta Utara, Indonesia \\ Telp: (021) 64711583 Fax: 64700924 \\ Diterima tanggal: 26 Agustus 2020; Diterima setelah perbaikan: 22 Desember2020; \\ Disetujui terbit: 28 Desember 2020
}

\begin{abstract}
ABSTRAK
Impor ikan salmon-trout semakin meningkat seiring bervariasinya menu masakan Jepang di Indonesia pada sejumlah hotel, restoran dan katering. Pengendalian impor terhadap komoditas harus dilakukan sebagai upaya mengurangi defisit neraca perdagangan. Pengendalian impor ikan salmon-trout sangat penting dilakukan karena merupakan produk pesaing ikan lokal dan berpotensi menurunkan permintaan terhadap ikan lokal. Oleh karena itu, penelitian ini bertujuan merumuskan strategi pengendalian impor ikan salmon-trout terutama untuk konsumsi hotel, restoran, katering, pasar modern (Horekapasmod) dan industri pengolahan ikan (re-ekspor). Data primer dan sekunder digunakan dalam penelitian ini. Data primer berasal dari wawancara dan diskusi dengan pemangku kepentingan impor salmon-trout pada bulan bulan Maret hingga September 2019 di DKI Jakarta dan Jawa Timur sebagai pintu masuk impor utama ikan salmon-trout. Data sekunder juga dikumpulkan dari berbagai institusi seperti BPS dan berbagai hasil penelitian beberapa perguruan tinggi. Data yang dikumpulkan kemudian dianalisis dengan menggunakan metode analysis hierarchy process (AHP) untuk merumuskan strategi pengendalian impor salmon-trout. Strategi pengendalian impor salmon-trout berdasarkan hasil analisis disusun berdasarkan prioritas. Prioritas pertama dengan bobot nilai 0,413 adalah sosialisasi dan edukasi kepada masyarakat tentang jenis ikan yang memiliki kandungan gizi sama dengan salmon-trout. Prioritas kedua adalah peningkatan ketersediaan dan perbaikan kualitas ikan lokal yang potensial mensubstitusi salmon-trout dengan bobot 0.363 . Prioritas ketiga adalah mengikuti kerjasama perdagangan internasional untuk ekspansi pasar ekspor khususnya untuk fillet salmon-trout dengan bobot sebesar 0,224. Pelaksanaan strategi tersebut diharapkan dapat meningkatkan konsumsi ikan lokal yang asupan gizinya tidak kalah dengan salmon-trout sehingga alokasi impor dalam negeri dapat dikurangi secara bertahap.
\end{abstract}

Kata Kunci: salmon-trout, pengendalian impor, analysis hierarchi process, konsumsi, pasar dalam negeri

\begin{abstract}
Salmon-trout imports has increased along with the growth of hotels, restaurants and restaurants with Japanese cuisine in Indonesia. Control of imports of commodities must be done as an effort to reduce the trade balance deficit. Import control of salmon-trout is very important because it is a local fish competitor and has the potential to reduce demand for local fish. Therefore, this study aims to formulate a salmon-trout import control strategy especially for hotels, restaurants, catering, retails and processing industry (re-export) consumption. Primary and secondary data were used in this study, primary data derived from interviews and discussions with salmon-trout importer stakeholders in March to September 2019 in DKI Jakarta and East Java as the main entry point for salmon-trout import. Secondary data was also collected and from various institutions such as BPS and various research results from several universities. The data collected then analyzed using the hierarchical process analysis (AHP) method to formulate salmon-trout import control strategies. Salmon-trout import control strategies based on the results of the analysis are arranged according to priority. The first priority with a weight value of 0.413 is socialization and education to the public about the types of fish that have the same nutritional content as Salmon-Trout. The second priority is increasing availability and improving the quality of local fish which
\end{abstract}


has the potential to substitute Salmon-Trout with a weight of 0.363 . The third priority is to participate in international trade cooperation for the expansion of export markets specifically for salmon-trout fillets with a weight of 0.224 . The implementation of this strategy is expected to increase the consumption of local fish which are nutritionally inferior to salmon-trout so that the allocation of imports is gradually reduced.

\section{Keywords: salmon-trout, import controls, hierarchical analysis process, consumption, domestic market}

\section{PENDAHULUAN}

Industri salmon hasil budidaya telah berkembang pesat selama empat dekade terakhir, permintaan salmon bahkan tidak dapat dipenuhi di banyak pasar terutama di belahan Asia (Helander, 2017). Bentuk produk utama perdagangan salmon adalah dalam bentuk segar. Pangsa impor salmon segar untuk pasar Uni Eropa dan Perancis relatif stabil pada periode tahun 1997-2009 yaitu sedikit di atas $60 \%$ dalam bentuk segar (Asche, Dahl, Gordon, Trollvi \& Aandhal, 2011; Xie, Kinnucan \& Myrland, 2009). Norwegia merupakan negara produsen utama dalam budidaya ikan salmon bahkan memproduksi lebih banyak dibandingkan Inggris, Chili, Kanada dan Kepulauan Faroe (FAO, 2015; Elvestad, 2009).

Salmon adalah salah satu jenis ikan yang tidak dimiliki Indonesia, sehingga kegiatan impor mau tidak mau harus dilakukan karena adanya permintaan terhadap komoditas ikan tersebut, kebijakan impor pun dengan volume terbatas. Salmon merupakan salah satu komoditas impor Indonesia yang pertumbuhannya terus meningkat dari tahun ke tahun. Saat ini impor salmon Indonesia hanya untuk konsumsi terbatas yaitu restoran, hotel, catering, pasar modern dan industri pengolahan ikan (re-ekspor dimana salmon sebagai bahan baku kemudian diolah untuk dikirim lagi ke pasar luar). Impor ikan salmon mengalami peningkatan seiring meningkatnya permintaan terhadap makanan sushi dan sashimi di Indonesia.

Pada era perdagangan global, kebijakan perdagangan menjadi sangat penting untuk mendorong percepatan pertumbuhan ekonomi, memperkuat ketahanan pangan, mengurangi kemiskinan dengan tetap mempertimbangkan perlindungan terhadap pelaku usaha dan industri domestik. Secara umum kebijakan perdagangan global pada dasarnya terdiri dari kebijakan ekspor dan kebijakan impor. Penelitian Indramadhini dan Sitompul (2015) menyatakan bahwa kegiatan impor dapat mengakibatkan dua permasalahan yang pertama apabila impor lebih besar daripada ekspor yang mengakibatkan cadangan devisa berkurang dan yang kedua apabila sebagian besar barangbarang impor merupakan barang konsumsi yang mengakibatkan menurunnya produktifitas dalam negeri. Dalam rangka memaksimalkan dampak positif dan meminimalkan dampak negatif kemudian pemerintah mengeluarkan kebijakan impor ikan di Indonesia melalui Peraturan Pemerintah no 9 Tahun 2018 tentang Tata Cara Pengendalian Impor Komoditas Perikanan dan Pegaraman sebagai Bahan Baku dan Bahan Penolong Industri serta pengaturannya tertuang dalam Peraturan Menteri Perdagangan No 66 Tahun 2018 tentang ketentuan impor hasil perikanan. PP no 9 Tahun 2018 mengatur mekanisme pengendalian impor yang mengatur penetapan tempat pemasukan, jenis dan volume, waktu pemasukan, serta pemenuhan persyaratan administratif dan standar mutu dimana untuk rekomendasi impor dikeluarkan oleh Kementerian Kelautan dan Perikanan dan izin impor dikeluarkan oleh Kementerian Perdagangan.

Pentingnya pengendalian impor pada berbagai komoditas barang konsumsi diantaranya bertujuan untuk mengurangi ketergantungan impor, penurunan harga dan produksi dalam negeri (Siswanto, Sinaga \& Harianto, 2018; Varina, 2018; Arthatiani \& Deswati, 2020). Demikian halnya dengan ikan salmon, kegiatan impor untuk pemenuhan kebutuhan bahan baku hotel, restoran, katering dan pasar modern perlu dikendalikan untuk melindungi pemanfaatan sumber daya perikanan Indonesia secara optimal. Oleh karena itu, strategi dalam pengendalian impor salmon-trout harus dikaji lebih lanjut agar pertumbuhan industri hotel dan restoran tetap berkembang dengan pertimbangan pemanfaatan sumberdaya perikanan yang ada di perairan Indonesia secara optimal.

Tujuan penelitian ini adalah untuk merumuskan strategi pengendalian impor salmontrout untuk konsumsi hotel, restoran dan katering dengan menggunakan metode analisis hierarki proses (AHP). Kegiatan penelitian dilakukan di DKI Jakarta dan Jawa Timuryang merupakan pintu masuk impor utama dan kota besar dengan pertumbuhan hotel, restoran dan katering yang tinggi pada bulan Maret hingga September 2019. Responden yang 
terlibat dalam penelitian ini ditentukan secara sengaja berdasarkan pertimbangan pengetahuan, kemampuan, dan pengalaman responden dalam proses impor salmon-trout sebanyak berjumlah 10 orang yang juga berperan sebagai pakar dalam proses analisis meliputi importir salmon, pengambil kebijakan, peneliti dan akademisi. Pemilihan strategi prioritas dari alternatif strategi yang disusun menggunakan Analitycal Hierarchy Process (AHP) yang selanjutnya dianalisis secara deskriptif. Penggunaan AHP dalam penelitian sudah banyak dilakukan khususnya untuk pemilihan kebijakan seperti yang dilakukan oleh Rostin, Nusanta, Rafiy, Rumbia, Putera dan Saranani (2018) pemilihan kebijakan pengembangan industri perikanan di Sulawesi Tenggara. Berbagai kajian kebijakan pemasaran produk juga banyak yang menggunakan AHP sebagai alat analisis pemilihan kebijakan seperti kajian Setala, Saarni \& Honkanen (2001), Ghodsypour \& O'Brien (1998) dan Tyagi (1997). Hasil penelitian diharapkan dapat membantu merumuskan kebijakan pengendalian impor salmon-trout yang tepat sehingga dapat mengurangi besaran impor yang tidak perlu dan tidak sesuai dengan kebutuhan pelaku usaha dalam hal ini hotel, restoran, katering, pasar modern dan re-ekspor.

\section{PERKEMBANGAN IMPOR SALMON-TROUT DI INDONESIA}

Impor komoditas perikanan hingga sekarang masih terus dilakukan meskipun jika dibandingkan dengan besaran ekspor perikanan nilai dan volumenya tidak terlalu besar. Pertumbuhan nilai impor perikanan secara rata-rata dari tahun 2012-2018 (BPS, tahun) mengalami pertumbuhan sebesar $1 \%$. Komoditas impor perikanan utama dikelompokkan menjadi 5 jenis yakni tepung ikan, mackerel, rajungan-kepiting, salmon-trout, dan lemak-minyak ikan dengan tren impor dijelaskan pada Gambar 1.

Berdasarkan Gambar 1 dapat diketahui dari nilai impor tepung ikan dan mackarel memiliki nilai impor yang paling tinggi dibandingkan komoditas lainnya, namun tepung ikan ada kecenderungan penurunan nilai impor setiap tahunnya meskipun masih menjadi komoditas impor yang terbesar. Hal tersebut ditunjukkan dengan pertumbuhan nilai impor tepung ikan secara rata-rata dari tahun 2012-2018 mengalami penurunan sebesar $3,45 \%$, sedangkan pertumbuhan nilai impor yang terbesar ditunjukkan oleh komoditas Salmontrout dengan nilai pertumbuhan sebesar $35,64 \%$. Komoditas mackarel nilai impornya relatif tetap dengan tingkat pertumbuhan rata-rata sebesar 2,79\% namun terjadi lonjakan pada tahun 2017 sebesar $68,01 \%$ yang kemungkinan disebabkan kelangkaan ikan lokal karena dampak kebijakan moratorium kapal.

Gambar 2 menunjukkan bahwa komoditas salmon-trout didominasi dari negara Norwegia dengan pangsa impor mencapai $41 \%$ dari total impor Salmon-Trout. Negara lainnya yang mengimpor Salmon ke Indonesia adalah Australia, Jepang dan Chile. Norwegia merupakan produsen utama salmon-trout terbesar didunia dengan keberhasilan budidaya marikultur untuk salmon-Trout. Hal ini yang menjadikan Norwegia menjadi importir terbesar salmon-trout di dunia termasuk ke Indonesia. Komoditas mackerel dan salmon-trout secara

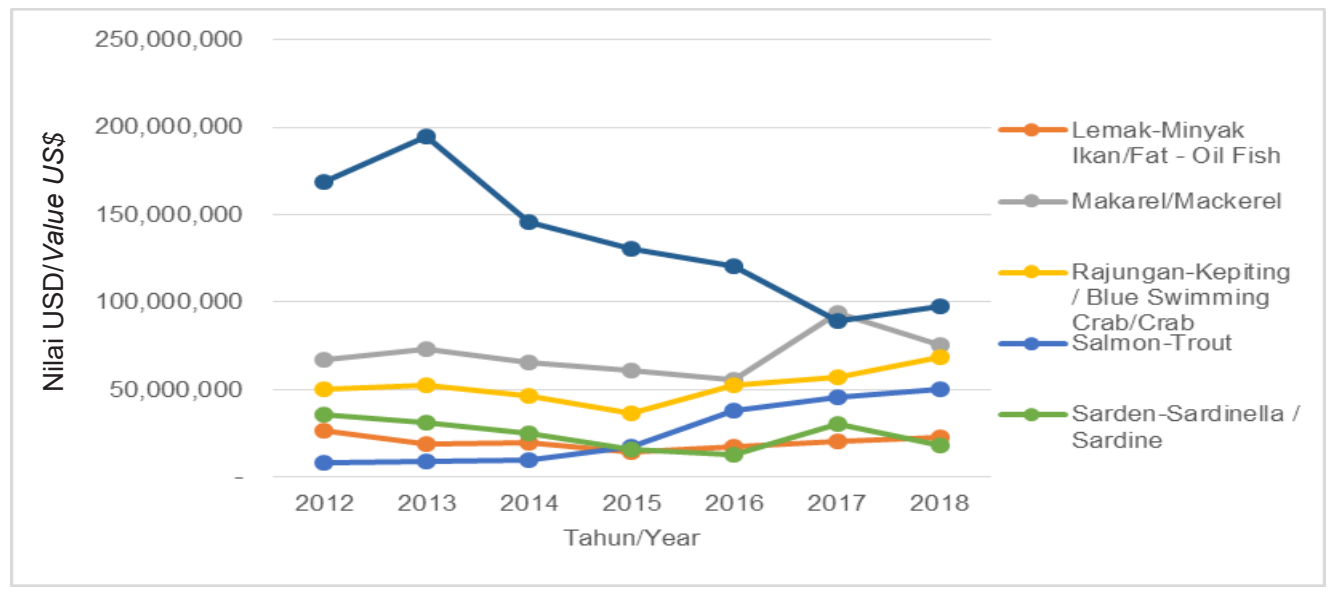

Gambar 1. Tren Nilai Impor Komoditas Perikanan Utama.

Figure 1. Trends in Import Value of Major Fisheries Commodities.

Sumber: BPS diolah 2019/Source:Central Bureau of Statistic Republic of Indonesia processed 2019 


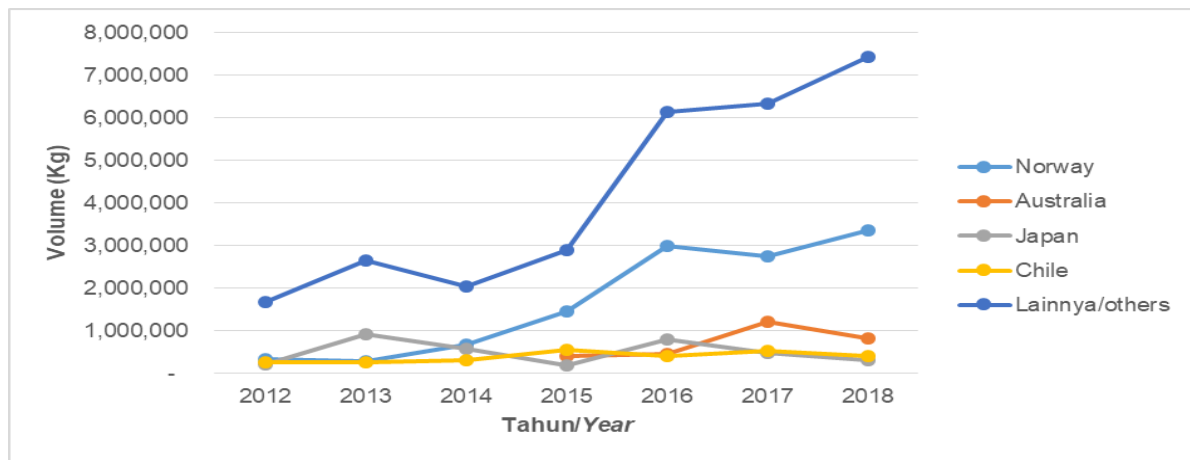

Gambar 2. Volume Impor Salmon-Trout berdasarkan Negara Importir Utama. Figure 2. Salmon-Trout Import Volume by Major Importing Countries.

Sumber: BPS diolah 2019/Source:Central Bureau of Statistic Republic of Indonesia processed 2019

alamiah tidak terdapat di perairan Indonesia, sehingga komoditas ini terus diimpor. Analisis lanjutan terkait peruntukan impor komoditas salmontrout dan upaya substitusi dengan ikan lokal harus dianalisis lebih lanjut. Harapannya penelitian ini dapat menghasilkan kebijakan yang tepat dalam upaya pengendalian impor salmon-trout namun tetap memperhatikan kebutuhan pelaku usaha dan masyarakat dalam arti luas.

Salmon merupakan jenis ikan dari famili Salmonidae. Ikan lain yang berada dalam satu famili dengan salmon adalah Trout. Kedua jenis ikan merupakan komoditas yang diimpor sebagai bahan baku untuk konsumsi domestik di hotel, restoran dan katering yang menyajikan menu masakan Jepang serta kembali diekspor setelah dilakukan pengolahan lebih lanjut. Berdasarkan Peraturan MKP No 15/MENKP/2011 jo KEP.025/ DJ-P2HP/2012 tentang Daftar Jenis-Jenis Hasil Perikanan yang dapat dimasukkan ke dalam Wilayah Negara RI, jenis Salmon dan Trout yang dapat diimpor dalam bentuk segar dan beku dengan jenis Trout (Salmo trutta, Oncorhynchus spp.) dan Salmon (Oncorhynchus spp., Salmo salar).

\section{DISTRIBUSI DAN PERUNTUKAN IMPOR SALMON DAN TROUT}

Impor Salmon dan Trout yang masuk ke Indonesia dalam bentuk segar, beku, fillet, diasapi, dalam kemasan kedap udara dan tidak dalam kemasan kedap udara. Berdasarkan data yang dikeluarkan oleh Badan Pusat Statistik tentang Ekspor-Impor Produk Perikanan tahun 2019, volume impor salmon-trout dominan pada bentuk segar dan beku. Volume impor salmon-trout pada tahun 2018 sebesar $6.190 .692 \mathrm{~kg}$ atau rata-rata pertumbuhan sebesar 7,2\% selama periode 2016-2018. Komposisi berdasarkan bentuk produk salmon-trout pada tahun 2018 didominasi dalam bentuk segar sebesar $63 \%$ dan beku sebesar $36 \%$, sedangkan sisa $1 \%$ dalam bentuk fillet, diasapi, dalam kemasan kedap udara dan tidak dalam kemasan kedap udara. Dominasi produk salmontrout segar dikarenakan kebutuhan hotel dan restoran dengan menu masakan Jepang dalam bentuk sushi atau sashimi. Secara lengkap impor salmon-trout Tahun 2016-2018 dapat dilihat pada Gambar 3.

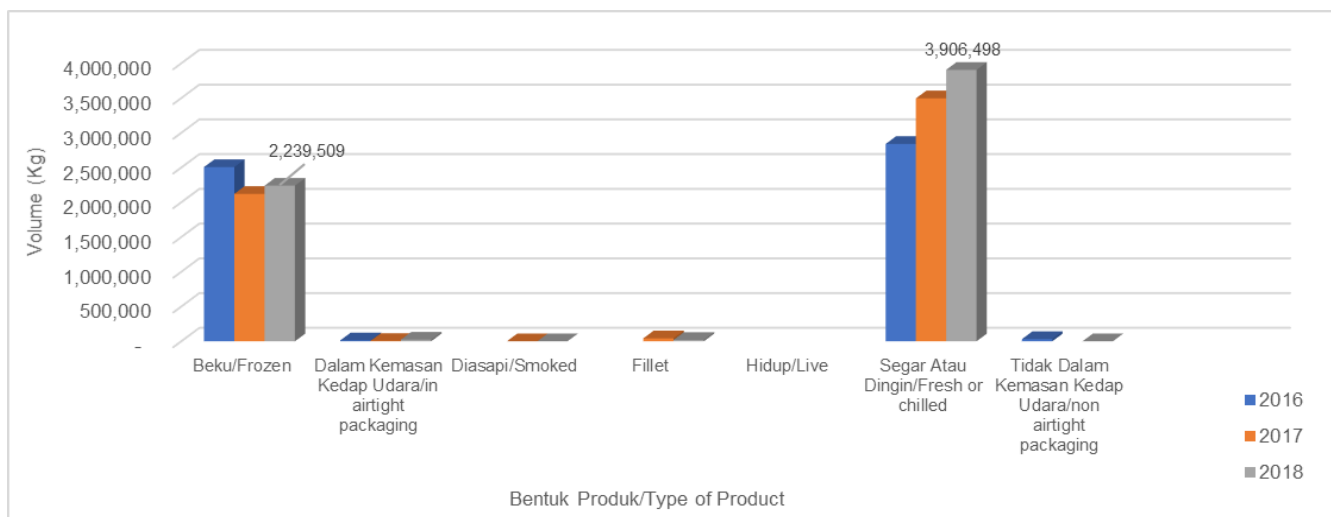

Gambar 3. Volume Impor Salmon dan Trout Tahun 2016-2018.

Figure 3. Imported Salmon and Trout Volume in 2016-2018.

Sumber: BPS diolah 2019/Source:Central Bureau of Statistic Republic of Indonesia processed 2019 
Berdasarkan lokasi bongkar muat, impor salmon-trout sebesar $58,20 \%$ melalui Bandara Soekarno Hatta, $14,49 \%$ melalui Pelabuhan Tanjung Priok, 25,66\% melalui Pelabuhan Tanjung Perak dan sisanya dari Bandara Ngurah Rai, Pelabuhan Belawan dan Pelabuhan Sekupang (Gambar 4).
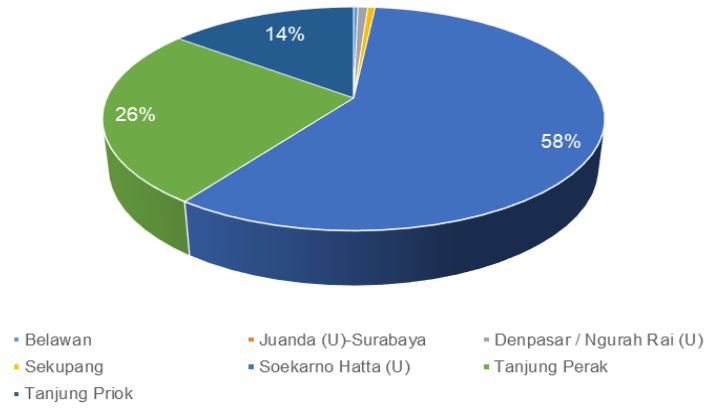

Gambar 4. Presentasi Rata-Rata Volume Impor Salmon dan Trout Berdasarkan Lokasi Bongkar Muat Tahun 2014-2019

Figure 4. Average of Salmon and Trout Import Volume by Loading and Unloading Location in 2014-2019.

Sumber: BPS diolah 2019/Source:Central Bureau of Statistic Republic of Indonesia processed 2019

Data ini sesuai dengan bentuk produk impor salmon-trout yang didominasi dalam bentuk segar, sehingga moda transportasi yang digunakan adalah pesawat, sedangkan impor salmon yang melalui pelabuhan umumnya dalam bentuk beku dan olahan lainnya. Berdasarkan hasil wawancara lapang dengan salah satu importir sekaligus trader ikan Salmon di Jakarta yaitu PT Masuya, impor salmon dalam bentuk utuh segar berasal dari Norwegia (60\%) dan Australia (40\%). Salmon tersebut langsung dijual utuh tanpa melalui proses apapun. Konsumen utama PT Masuya adalah Hotel bintang 5 dan restoran Jepang di Jakarta serta pasar modern seperti Fresh Market, Ranch Market, Hypermart dan Lulu.

Salah satu perusahaan importir Salmon di Pasuruan yaitu PT. Baramuda Bahari yang menyatakan bahwa komoditas Salmon utuh beku yang diimpor berasal dari Turki, Norwegia dan Rusia. Sejak tahun 2017, jumlah impor yang dilakukan perusahaan ini mengalami peningkatan yang signifikan, dimana pada tahun 2017 sebanyak 137 ton, dan meningkat tahun 2018 mencapai 432 ton. Sementara itu, bentuk olahan salmon yang dhasilkan berupa sashimi dan fillet yang hanya menggunakan dagingnya saja. Sedangkan untuk limbah yang dihasilkan berupa kepala, tulang, daging belakang, tulang leher dibeli oleh masyarakat lokal untuk dijadikan bahan baku tepung ikan.

Perusahaan importir di Pasuruan PT. Marine Cipta Agung (MCA) merupakan salah satu industri kawasan berikat yang juga melakukan impor Salmon dalam bentuk beku, memiliki unit usaha sebagai feed processing untuk ikan mackerel, sarden dan salmon. Bahan baku Salmon berasal dari Rusia (50-60\%) sisanya dari USA dan Jepang dengan jenis ikan Pacific Salmon yang diimpor dalam bentuk beku (utuh dan chunk). Konsumen PT. MCA adalah 4 perusahaan Jepang dengan kebutuhan bahan baku Salmon sebanyak 6-7 ton/bulan yang jika diolah menghasilkan $60-70 \%$ dari total bahan baku. Sama halnya dengan PT. Baramuda, limbah yang dihasilkan dalam processing (tulang, kepala dan lainnya) dibeli oleh masyarakat lokal yang dapat mencapai 1-2 ton/hari dengan harga jual

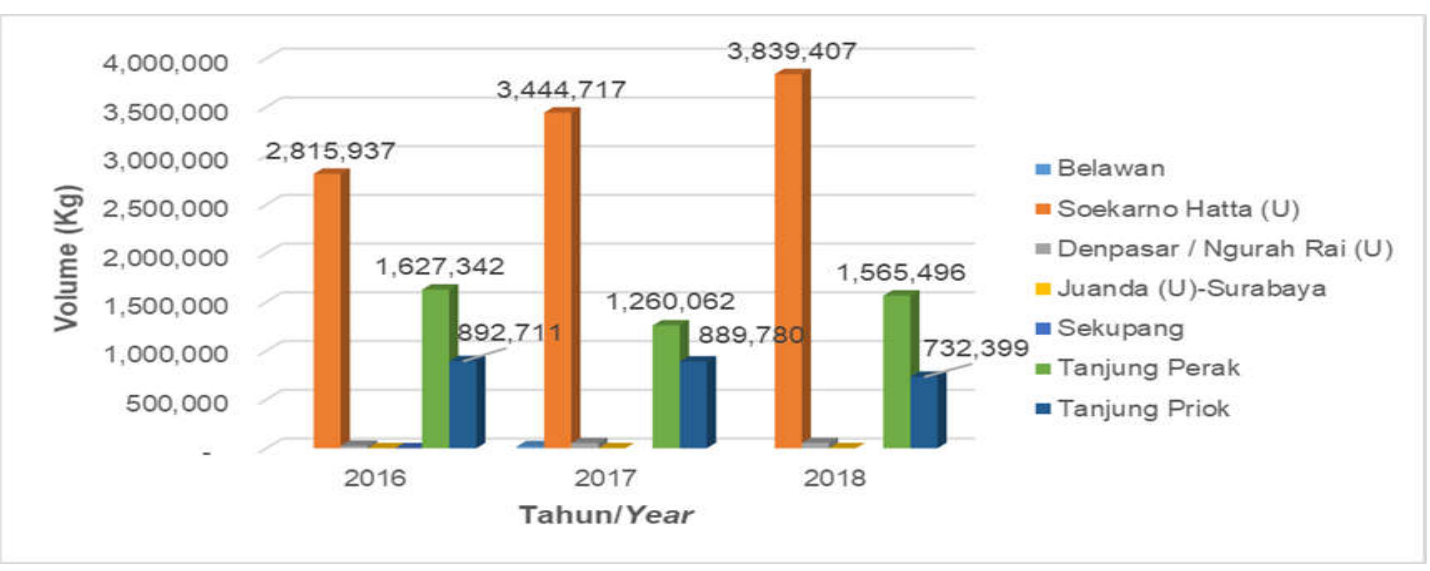

Gambar 5. Volume Impor Salmon dan Trout Berdasarkan Lokasi Bongkar Muat Tahun 2016-2018. Figure 5. Imported Salmon and Trout Volume Based on Loading Location in 2016-2018.

Sumber: BPS diolah 2019/Source:Central Bureau of Statistic Republic of Indonesia processed 2019 
Rp1.100/kg. Dua lokasi utama bongkar muat impor salmon-trout ini menunjukkan bahwa Jakarta dan Surabaya merupakan pasar utama impor Salmon dan Trout karena banyak hotel maupun restoran yang menyajikan menu salmon-trout di kedua lokasi ini.

Volume impor salmon-trout melalui Bandara Soekarno Hatta mengalami pertumbuhan sebesar $17 \%$ pada periode 2016-2019, impor melalui Pelabuhan Tanjung Perak hanya sebesar 1\% pada periode yang sama, sedangkan impor melalui Pelabuhan Tanjung Priok justru mengalami penurunan rata-rata sebesar $9 \%$ pada periode yang sama. Kondisi ini menunjukkan bahwa permintaan terhadap salmon-trout dalam kondisi segar terus mengalami permintaan seiring pertumbuhan hotel dan restoran yang menyajikan masakan Jepang di Jakarta. Gambar 5 menunjukkan Volume Impor salmon-trout pada lokasi bongkar muat tahun 2016-2018.

Produk impor salmon-trout peruntukannya adalah untuk bahan baku industri dan selain industri. Untuk kebutuhan selain industri, sesuai Pasal 4 pada Permen KP RI Nomor 58/PermenKP/2018 meliputi : pemindangan, umpan, konsumsi hotel, restoran dan katering, pasar modern, bahan pengayaan makanan atau bahan produk olahan berbasis daging lumatan. Peruntukan salmontrout selain industri digunakan oleh konsumsi hotel, restoran, katering dan pasar modern sebesar $76,78 \%$ untuk konsumen domestik, sedangkan Salmon untuk kebutuhan industri fillet yang kemudian diekspor adalah sebesar 23,32\% (Gambar 6).

\section{a. Hotel, Restoran, Katering dan Pasar Modern (Horekapasmod)}

Bisnis makan dan minuman di berbagai belahan dunia tercatat mengalami pertumbuhan yang sangat pesat (Nonto, 2006; dalam Sari 2006).
Demikian halnya di Indonesia, industri pangan dari tahun ke tahun semakin berperan penting dalam pembangunan industri nasional serta mendorong pertumbuhan ekonomi secara keseluruhan. Bisnis makanan berpotensi sangat besar karena makanan merupakan kebutuhan pokok yang harus dipenuhi. Kesibukan masyarakat terutama di kota besar seperti Jakarta dan Surabaya ikut mempercepat pertumbuhan bisnis makanan siap saji. Hal ini dikarenakan kesibukan masyarakat modern saat ini yang memiliki keterbatasan waktu untuk menyiapkan makanan sehingga merubah perilaku konsumsi untuk makan di luar rumah misalnya di restoran. Berbagai jenis restoran tumbuh dari yang sederhana (kaki lima) hingga yang mewah (hotel berbintang) yang menawarkan variasi produk olahan makanan dan minuman. Restoran makanan Jepang merupakan salah satu variasi restoran yang berkembang saat ini seiring pertumbuhan industri makanan. Kesadaran masyarakat akan pentingnya makanan bergizi dan berkualitas turut mendorong tumbuhnya restoran Jepang dengan berbagai skala usaha di Indonesia. Dengan demikian potensi pertumbuhan restoran makanan Jepang diindikasikan akan terus bertambah untuk memenuhi kebutuhan konsumen pada pentingnya kesehatan.

Sajian menu pada restoran Jepang yang menggunakan bahan dasar salmon dalam bentuk mentah seperti sushi dan sashimi, sedangkan pada restoran yang menyajikan makanan barat salmon umumnya diolah menjadi steak atau burger. Pangsa pasar inilah yang kemudian menjadi salah satu faktor yang mendorong impor ikan salmon baik dalam bentuk segar, beku atau olahan lainnya. Ikan salmon bentuk segar umumnya dikonsumsi oleh hotel dan restoran kelas menengah-atas, karena dari harga jual yang tinggi serta kualitas kesegaran yang harus dijaga. Studi kasus di Surabaya, Salmon diimpor dari Norwegia dan Australia (Tazmania) jika dalam bentuk segar dikirim melalui

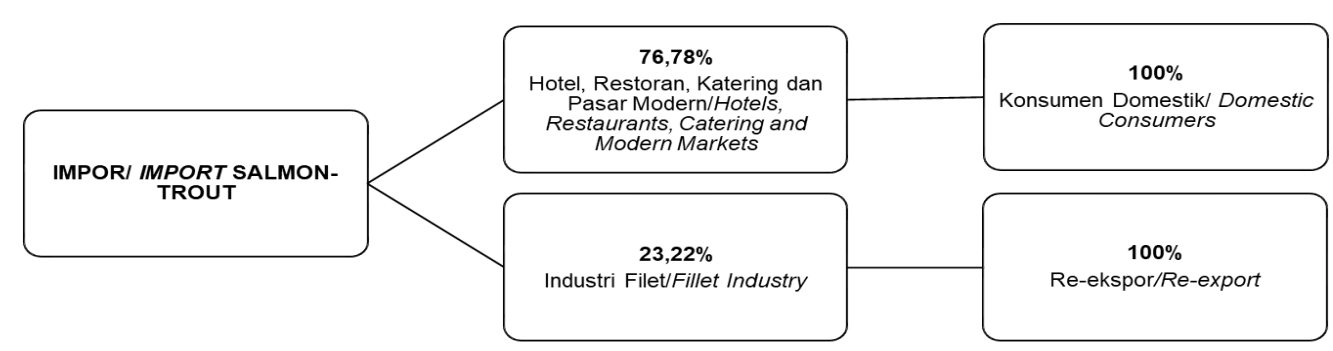

Gambar 6. Impor Salmon-Trout berdasarkan Peruntukan dan Pasar. Figure 6. Salmon-Trout Imports by Designation and Market.

Sumber : Data primer diolah, 2019/Source : Primary Data Processed, 2019 
Jakarta (Bandara Soekarno Hatta) sedangkan Salmon beku bisa langsung ke Surabaya melalui Pelabuhan Tanjung Perak. Salmon impor tersebut kemudian didistribusikan oleh trader ke hotel sekitar $60 \%$, restoran $30 \%$ serta katering dan pasar modern masing-masing $5 \%$ yang kemudian tentunya dikonsumsi oleh konsumen domestik baik masyarakat lokal maupun ekspatriat yang tinggal di Surabaya (Gambar 7).

\section{B. Industri Fillet}

Salmon sebagai bahan baku untuk industri sebesar $23 \%$ dari total impor, industri pengolahan salmon hanya berupa fillet dan pengasapan saja yang kemudian didistribusikan untuk konsumsi lokal sekitar $4 \%$ dan sisanya diekspor kembali (re-ekspor) sebesar 96\%. Negara tujuan ekspor Salmon sekitar $81 \%$ dengan tujuan Jepang, $7 \%$ tujuan ekspor ke Hongkong dan sisanya dengan negara tujuan ekspor Korea, Filipina, Singapura, Thailand dan Vietnam (BPS, 2019). Ekspor Salmon -Trout selama periode 2016-2018 mengalami penurunan, hal ini diindikasikan karena aktivitas pengolahan Salmon sangat tergantung pada pembeli (buyer), kebanyakan perusahaan belum memiliki kemampuan untuk ekspansi pasar sehingga sangat bergantung pada pemesanan dari buyer saja. Penurunan jumlah re-ekspor salmon-trout dari Indonesia diindikasikan karena kenaikan harga salmon di dunia sebesar $11 \%$ pada tahun 2018 .

Aktivitas ekspor Salmon umumnya dilakukan oleh perusahaan importir dengan tujuan ekspor kembali di kawasan berikat. Kawasan berikat merupakan suatu kawasan dengan batas tertentu yang didalamnya dilakukan kegiatan usaha industri pengolahan barang dan bahan, kegiatan rancang bangun, perekayasaan, penyortiran, pemeriksaan awal, pemeriksaan akhir, pengepakan atas barang dan bahan asal impor atau barang dan bahan dari dalam Daerah Pabean Indonesia Lainnya (DPIL) yang hasilnya terutama untuk tujuan ekspor. Fasilitas kepabeanan dan perpajakan yang diberikan kepada perusahaan di kawasan berikan ini diantaranya penangguhan bea masuk dan tidak dipungut Pajak Pertambahan Nilai (PPN), Pajak Penjualan atas Bawang Mewah (PPnBM) dan Pajak Penghasilan (PPh) Pasal 22 serta pembebasan cukai atas impor barang dan atau bahan untuk diolah lebih lanjut maupun atas pemasukan Barang Kena Cukai (BKC) dari DPIL untuk diolah lebih lanjut).

\section{FAKTOR PENDORONG IMPOR}

Berbagai penelitian mengungkapkan faktorfaktor yang mempengaruhi impor maupun ekspor untuk berbagai komoditas pangan dan non pangan diantaranya pendapatan masyarakat, selera konsumen, nilai tukar mata uang, ongkos angkut barang antar negara serta kebijakan pemerintah mengenai perdagangan internasional (Mankiw, 2000; Sukirno, 2000; Efendi, 2009; Imam, 2013; Pakpahan, 2012; Putri, 2017). Kerjasama perdagangan internasional dalam bentuk ekspor maupun impor terjadi karena adanya beberapa faktor pendorong yang mengharuskan suatu negara mengadakan kerjasama di bidang perdagangan. Krugman \& Maurice (2000) menjelaskan ada beberapa faktor-faktor yang mendorong dilakukannya impor antara lain: (a) keterbatasan kualitas sumber daya manusia dan teknologi yang dimiliki untuk mengolah sumber daya alam yang tersedia agar tercapai efektifitas dan efisiensi yang optimal dalam kegiatan produksi dalam negeri; (b) adanya barang-jasa yang belum atau tidak dapat diproduksi di dalam negeri; dan (c) adanya jumlah atau kuantitas barang di dalam negeri yang belum mencukupi. Setiap negara tidak dapat sepenuhnya memenuhi kebutuhan

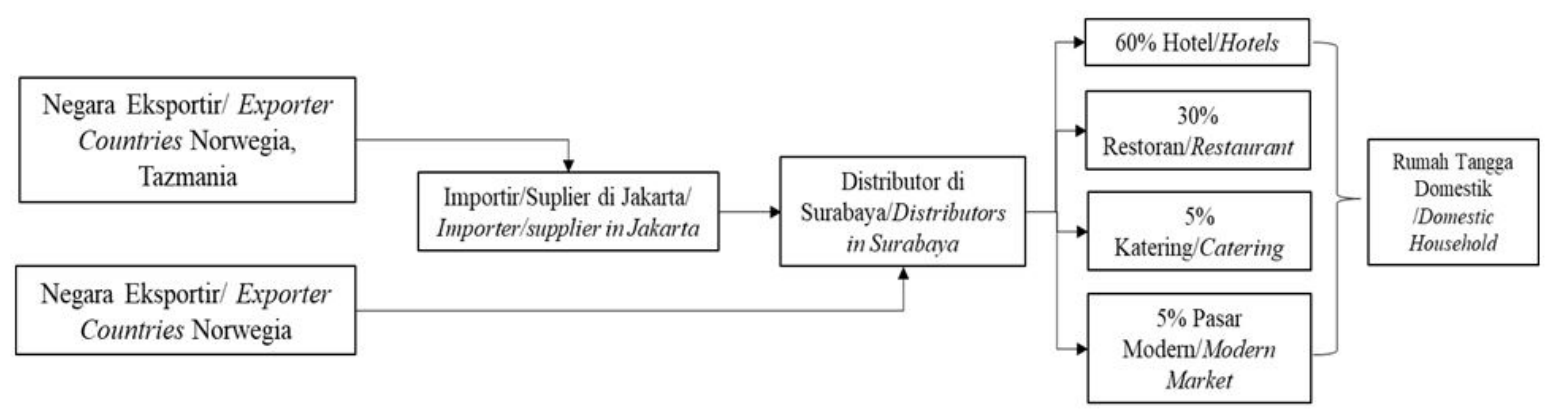

Gambar 7. Peruntukan Impor Salmon-Trout Selain Bahan Baku dan Bahan Penolong Industri di Surabaya.

Figure 7. Allocation of Salmon-Trout Imports Apart from Raw Materials and Industrial Supporting Materials in Surabaya.

Sumber : Data primer diolah, 2019/Source : Primary Data Processed, 2019 
negaranya sendiri tanpa adanya sumber daya dari negara lain, misalnya dalam hal sumber daya alam, sumber daya manusia, permodalan maupun teknologi. Faktor pendorong impor salmon-trout akan dibahas berdasarkan 5 indikator utama yaitu manusia, teknologi, material, metode dan lingkungan sesuai peruntukannya yaitu Horekapasmod dan industri yang dijelaskan dalam Tabel 1.

\section{A. Manusia}

Salmon umumnya merupakan hidangan di hotel maupun restoran Jepang yang terus mengalami pertumbuhan. Perkembangan jumlah wisatawan Jepang yang datang ke Indonesia menjadi potensi konsumen salmon-trout di hotel dan restoran yang menyajikan menu Salmon. Data BPS tahun 2018 menunjukkan bahwa pertumbuhan jumlah wisatawan Jepang ke Indonesia sebesar 5\% periode 2000-2017 atau sekitar 573.310 orang pada tahun 2017 .

Pertumbuhan restoran skala menengah dan besar di Indonesia sebesar $46 \%$ pada tahun 2011 dari tahun 2007 berdampak pula pada penyerapan tenaga kerja yang meningkat dari rata-rata sebanyak 27 orang per unit usaha restoran menjadi 28 orang per unit usaha atau sebesar $47,7 \%$ pada periode yang sama (Tabel 2). Tumbuhnya restoran skala kecil juga semakin marak dengan perkembangan jasa online, bahkan warung/café kaki lima di pinggir jalan sudah mulai menjamur dengan menu masakan Jepang. Impor Salmon juga membuka usaha pengolahan Salmon fillet dan asap baik untuk konsumsi lokal maupun ekspor. Tumbuhnya industri pengolahan Salmon tentunya membutuhkan tenaga kerja yang terampil, sehingga pertumbuhan penyerapan tenaga kerja akan meningkat seiring pertumbuhan industri ini.

\section{B. Mesin dan Teknologi}

Pemanfaatan kapasitas pabrik pengolahan yang belum optimal merupakan faktor pendorong lainnya untuk meningkatkan impor salmontrout untuk kemudian di ekspor. Utilisasi industri pengolahan perikanan saat ini sekitar $36,1 \%$ untuk skala menengah besar. Hal ini berarti industri pengolahan perikanan rata-rata

Tabel 1. Indikator Fishbone Diagram Faktor Pendorong Impor Salmon-Trout. Table 1. Fishbone Indicator Diagram of Drivers for Importing Salmon-Trout.

\begin{tabular}{|c|c|c|}
\hline $\begin{array}{l}\text { Indikatorl } \\
\text { Indicators }\end{array}$ & $\begin{array}{c}\text { Hotel, Restoran, Katering dan Pasar Modern/ } \\
\text { Hotels, Restaurants, Catering and Modern } \\
\text { Markets }\end{array}$ & $\begin{array}{l}\text { Industri Filet/ } \\
\text { Fillet Industry }\end{array}$ \\
\hline Manusia/Human & $\begin{array}{l}\text { - } \quad \text { Preferensi Konsumen/Consumers Preference } \\
\text { - Kebutuhan Ekspatriat dan Konsumen High- } \\
\text { Endl Needs of Expatriates and High-End } \\
\text { Consumers } \\
\text { - Peningkatan wisatawan, hotel dan restoran/ } \\
\text { Increase in tourists, hotels and restaurants } \\
\text { - Penyerapan Tenaga kerja/Employment }\end{array}$ & $\begin{array}{l}\text { Ketersediaan tenaga kerja untuk } \\
\text { pengolahan salmon/ } \\
\text { Availability of labor for processing } \\
\text { salmon }\end{array}$ \\
\hline $\begin{array}{l}\text { Mesin dan Teknologi/ } \\
\text { Machine and Technology }\end{array}$ & $\begin{array}{l}\text { Ketersediaan cold storage, freezer maupun es } \\
\text { untuk menjaga kesegaran ikan melalui sistem } \\
\text { rantai dingin/ Availability of cold storage, freezer } \\
\text { and ice to maintain the freshness of fish through } \\
\text { the cold chain system }\end{array}$ & $\begin{array}{l}\text { Memanfaatkan kapasitas pabrik } \\
\text { pengolah perikanan yang belum } \\
\text { optimal/ Utilizing the capacity of fisheries } \\
\text { processing factories that are not yet } \\
\text { optimal }\end{array}$ \\
\hline Material/ Material & $\begin{array}{l}\text { Citarasa Ikan Domestik Belum Bisa } \\
\text { Menggantikan Salmon/ Domestic Fish Flavor Can } \\
\text { Not Replace Salmon }\end{array}$ & $\begin{array}{l}\text { Impor Salmon untuk Kawasan Berikat } \\
\text { tidak dibatasi kuota/ } \\
\text { Salmon imports for bonded zones are } \\
\text { not limited to quotas }\end{array}$ \\
\hline Metode/Method & $\begin{array}{l}\text { - Perkembangan transportasi, komunikasi dan } \\
\text { jasa online/ The development of transportation, } \\
\text { communication and online services } \\
\text { - Pengolahan salmon untuk konsumsi rumah } \\
\text { tangga mudah dan sederhana/ Processing } \\
\text { salmon for household consumption is easy and } \\
\text { simple }\end{array}$ & $\begin{array}{l}\text { Biaya pengolahan Salmon di Indonesia } \\
\text { masih bersaing/ } \\
\text { Salmon processing costs in Indonesia } \\
\text { are still competitive }\end{array}$ \\
\hline $\begin{array}{l}\text { Lingkungan/ } \\
\text { Environment }\end{array}$ & $\begin{array}{l}\text { - Ikan Salmon tidak ada di Indonesia/ Salmon is } \\
\text { not found in Indonesia } \\
\text { - Perkembangan tren kuliner makanan jepang/ } \\
\text { Development of Japanese food culinary trends }\end{array}$ & $\begin{array}{l}\text { - Adanya fasilitas kawasan berikat } \\
\text { untuk produk re-ekspor/ There is a } \\
\text { bonded zone facility for re-export } \\
\text { products }\end{array}$ \\
\hline
\end{tabular}

Sumber : Data primer diolah, 2019/Source : Primary Data Processed, 2019 
Tabel 2. Perkembangan Jumlah Restoran Skala Menengah dan Besar serta Tenaga Kerja Restoran Indonesia Tahun 2007 -2011.

Table 2. Development of the Number of Middle and Large Scale Restaurants and Indonesian Restaurant Workers in 2007-2011.

\begin{tabular}{lrrrrr}
\hline \multicolumn{1}{c}{ Uraian/Description } & 2007 & $\mathbf{2 0 0 8}$ & $\mathbf{2 0 0 9}$ & $\mathbf{2 0 1 0}$ & 2011 \\
\hline Restoran (unit)/Restaurants (unit) & 1.615 & 2.235 & 2.704 & 2.916 & 2.977 \\
Tenaga Kerja (orang)/ Workers (person) & 43.605 & 60.345 & 73.008 & 78.732 & 83.356 \\
\hline
\end{tabular}

Sumber: BPS, 2012/Source:Central Bureau of Statistic Republic of Indonesia, 2012

hanya mengoperasikan sekitar $36 \%$ dari total kapasitas. Untuk industri olahan salmon-trout ketergantungan terhadap buyer sangat tinggi, karena industri ini merupakan penyedia jasa processing, bahan baku milik buyer serta negara tujuan ekspor pun sesuai permintaan pembeli/ pengguna jasa. Peningkatan utilitas industri pengolahan dapat dilakukan jika perluasan pasar dilakukan oleh industri tidak hanya bergantung pada pembeli/pengguna jasa saat ini. Artinya industri harus memiliki informasi pasar negara eksportir yang dituju dengan berbagai persyaratan yang harus dipenuhi.

\section{Material}

Pertumbuhan ekonomi Indonesia tahun 2018 sebesar 5,17\%, sektor konsumsi masih menjadi motor penggerak ekonomi Indonesia dengan persentase 56,01\% (Laucereno, 2019). Transportasi, komunikasi dan restoran tumbuh cepat dengan adanya peralihan behaviour konsumen rumah tangga ketika makanan menjadi mudah diperoleh melalui jasa online. Kondisi ini juga menjadi faktor pendorong peningkatan impor salmon di Indonesia. Kebijakan tidak ada pembatasan dengan kuota impor bagi industri di kawasan berikat, penangguhan bea masuk dan tidak dipungut PPN, PPNBM dan PPh Pasal 22 serta pembebasan cukai atas impor merupakan faktor pendorong lainnya untuk peningkatan impor salmon.

\section{Metode}

Penyajian menu berbahan salmon seperti sushi dan sashimi pada restoran Jepang relatif mudah. Kunci utama dalam pengolahan ikan salmon ini adalah menjaga kesegaran ikan sehingga layak dan aman untuk dikonsumsi. Kemudahan dalam metode pengolahan salmon menyebabkan tumbuhkan warung/café masakan Jepang skala kecil, bahkan ibu rumah tangga pun dapat mengolah sendiri dengan menggunakan salmon beku yang bisa diperoleh di pasar modern. Pada industri salmon, biaya pengolahan Salmon di Indonesia masih dapat bersaing, khususnya industri pada kawasan berikat karena biaya-biaya pajak serta cukai impor mengurangi biaya operasional yang harus dikeluarkan.

\section{E. Lingkungan}

Faktor pendorong terjadinya impor salmontrout dari sisi lingkungan adalah sumber daya ikan tersebut yang memang tidak ada di Indonesia, karena kondisi iklim yang tidak sesuai dengan habitat hidup Salmon-Trout. Dari sisi lingkungan masyarakat, pergeseran pola makan masyarakat ke arah makanan sehat menjadi faktor pendorong lainnya impor salmon menjadi semakin meningkat. Tren kuliner masakan Jepang juga semakin berkembang mulai kelas menengah-atas hingga kaki lima. Manfaat adanya impor salmon-trout antara lain:

1. Dapat memperoleh produk yang tidak bisa dihasilkan sendiri karena adanya perbedaan sumber daya alam.

2. Pemenuhan sumber gizi protein hewani.

3. Menambah devisa negara dari aktivitas horekapasmod serta hasil ekspor salmon.

4. Membuka lapangan kerja, dengan tumbuhnya horeka dengan menu salmon serta pasar modern maka kesempatan kerja akan semakin terbuka bagi masyarakat lokal.

Meskipun impor salmon-trout memberikan manfaat bagi negara dan masyarakat, pemerintah melalui kebijakan perdagangan internasionalnya harus tetap memberlakukan kuota atau batasan impor, dengan tujuan melindungi komoditas perikanan yang ada di Indonesia. Bahkan nilai gizi ikan yang ada di Indonesia tidak kalah tinggi dibandingkan salmon seperti ikan tuna, ikan sebelah dan ikan lele. 
STRATEGI PENGENDALIAN IMPOR SALMONTROUT

Struktur hierarki dalam analisis meliputi lima level hirarki yaitu level 1 fokus, level 2 faktor, level 3 aktor, level 4 tujuan dan level 5 strategi (Gambar 8). Berdasarkan hasil focuss group discussion dengan para informan kunci yaitu orang yang dianggap expert pada bidang impor ikan salmon, terdapat empat faktor utama yang berpengaruh terhadap strategi pengendalian impor ikan salmon-trout yang dilakukan oleh para pelaku usaha (level 2) yaitu ekonomi, kebijakan, sumberdaya dan sosial. Aktor pada level 3 yang dianggap berpengaruh dalam kegiatan impor tersebut adalah pemerintah dalam hal ini adalah Kementerian Kelautan dan Perikanan, pelaku usaha perikanan salmon baik importir, pengolah ikan salmon serta masyarakat umum sebagai konsumen rumah tangga. Tujuan strategi pengendalian impor lainnya adalah (1) menurunkan impor dan (2) meningkatkan produksi ikan substitusi. Alternatif strategi pada level 5 yaitu (1) sosialisasi dan edukasi pada masyarakat mengenai jenis-jenis ikan yang kandungan gizinya tidak kalah dengan ikan salmon, (2) peningkatan ketersediaan dan perbaikan kualitas ikan lokal sebagai substitusi dan (3) peran aktif diplomasi perdagangan Indonesia dalam pertemuan internasional perlu ditingkatkan untuk menjaring kerjasama internasional serta memperluas ekspansi pasar. Berikut struktur hierarki strategi pengendalian impor yang dihasilkan penelitian ini dapat dilihat pada Gambar 8.

Proses pembobotan pada setiap level hirarki dilakukan dengan membandingkan masing-masing atribut untuk mendapatkan nilai terlemah dan terkuat antar atribut. Pembobotan dilakukan karena masing-masing kriteria dalam setiap level memiliki tingkat kepentingan yang berbeda.

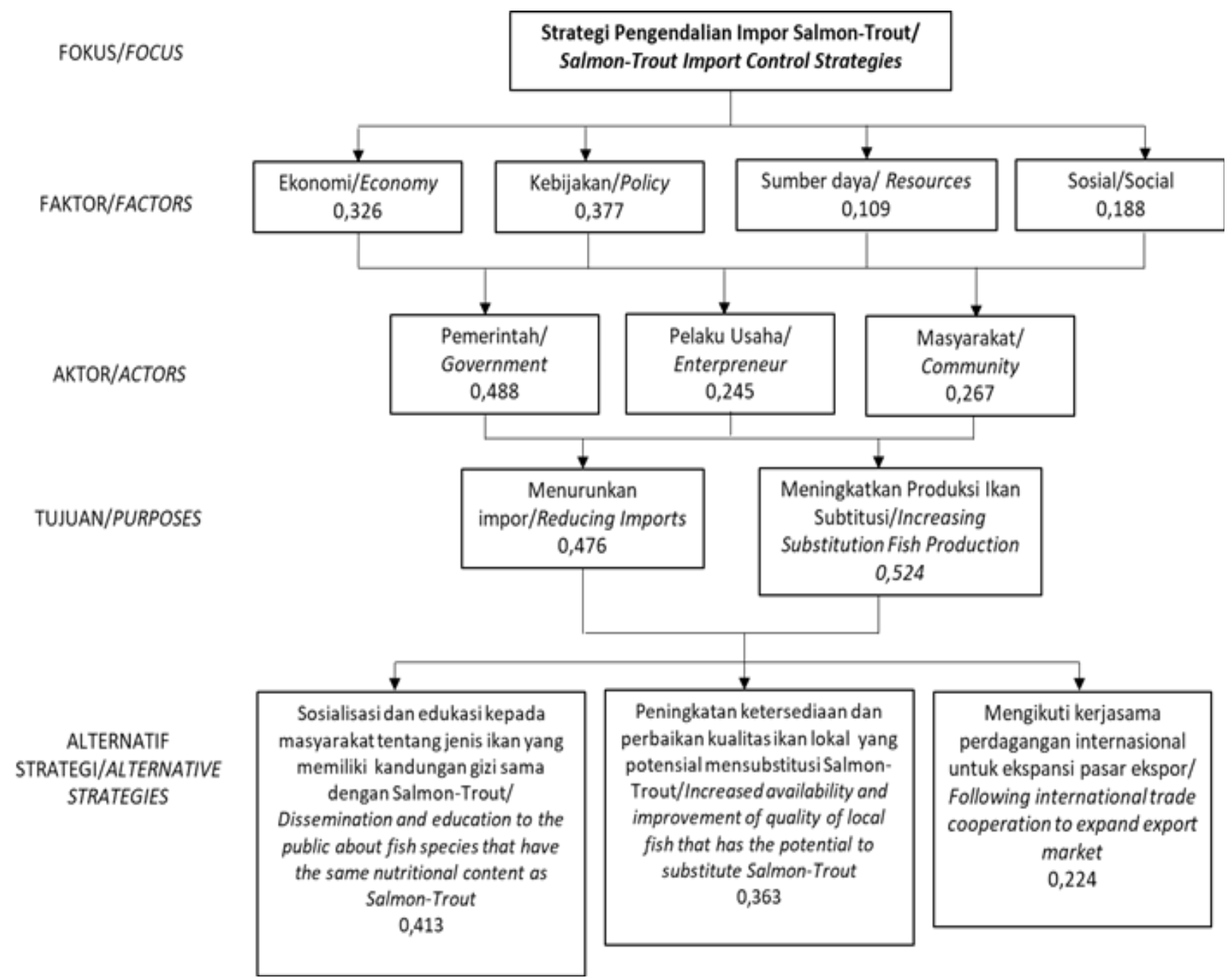

Gambar 8.Struktur Hirarki Strategi Pengendalian Impor Ikan Salmon-Trout. Figure 8: Hierarchy Structure of Salmon-Trout Import Control Strategy. 


\section{Peranan Aktor dalam Pengendalian Impor Salmon-Trout}

Pengolahan pada level aktor menunjukan tingkat pengaruh aktor terhadap faktor. Berdasarkan Tabel 3 terlihat bahwa pemerintah $(0,594)$ bertanggung jawab penuh dari sisi ekonomi seperti mencari cara untuk mengendalikan impor ikan salmon-trout yang tidak merugikan pelaku usaha dan juga pemerintah. Selain itu pada faktor sumberdaya pemerintah juga bertanggung jawab dalam hal mencari dan menemukan jenis ikan lokal yang memiliki kandungan gizi yang sama dengan ikan salmon-trout sehingga bisa direferensikan menjadi ikan subtitusi. Sedangkan pada faktor kebijakan terlihat aktor yang paling berpengaruh adalah masyarakat $(0,584)$ karena kebijakan yang telah ditetapkan suatu pemerintahan bisa berjalan baik jika masyarakatnya mematuhi dan melaksanakan kebijakan tersebut.
Dari Tabel 4 terlihat berbagai kepentingan dari masing-masing aktor dalam mencapai tujuan yang akan dicapai dimana dalam hal ini aktor yang terlibat adalah pemerintah, pelaku usaha dan masyarakat umum. Tujuan yang akan dicapai hanya dua jenis yaitu menurunkan impor dan meningkatkan produksi ikan subtitusi yang bisa diawali dengan meneliti atau mengedukasi mengenai jenis-jenis ikan yang bisa digunakan sebagai pengganti ikan salmon. Upaya pencapaian tujuan tersebut juga dibandingkan peran masing-masing aktor dalam tiap aspek yang dijadikan indikator yaitu ekonomi, sosial, kebijakan dan sumberdaya.

Aktor yang berkepentingan dalam pencapaian tujuan pertama terletak di pemerintah karena memang penurunan atau pengurangan jumlah impor salmon/trout sudah menjadi tugas utama baik dari Kementerian Kelautan dan

Tabel 3. Pengolahan Bobot Nilai Aktor dalam Pengendalian Impor Salmon-Trout.

Table 3. Processing Value Weight of Actors in Salmon-Trour Import Control.

\begin{tabular}{lcccc}
\hline \multirow{2}{*}{ Aktor/Actors } & \multicolumn{4}{c}{ Faktor/Factors } \\
\cline { 2 - 5 } & $\begin{array}{c}\text { Ekonomi/ } \\
\text { Economy }\end{array}$ & $\begin{array}{c}\text { Kebijakan/ } \\
\text { Policy }\end{array}$ & $\begin{array}{c}\text { Sumber Daya/ } \\
\text { Resources }\end{array}$ & $\begin{array}{c}\text { Infrastrukturl } \\
\text { Infrastructure }\end{array}$ \\
\hline Pemerintah/Government & 0.594 & 0.281 & 0.594 & 0.484 \\
Pelaku Usaha/Entepreneur & 0.249 & 0.135 & 0.247 & 0.349 \\
Masyarakat/Community & 0.157 & 0.584 & 0.157 & 0.168 \\
\hline
\end{tabular}

Sumber : Data primer diolah, 2019/Source : Primary Data Processed, 2019

Tabel 4. Pengolahan Bobot Nilai Tingkat Tujuan dalam Pengendalian Impor Salmon-Trout. Table 4. Processing Value Weight of Goal Level in Salmon-Trour Import Control.

\begin{tabular}{lcc}
\hline \multicolumn{1}{c}{ Aktor/Actors } & \multicolumn{2}{c}{ Tujuan/Goal } \\
\cline { 2 - 3 } & $\begin{array}{c}\text { Meningkatkan Produksi Ikan } \\
\text { Reducing Imports }\end{array}$ & $\begin{array}{c}\text { Subtitusi/Increasing Substitution } \\
\text { Fish Production }\end{array}$ \\
\hline Ekonomi/Economy & 0.750 & 0.250 \\
Pemerintah/Government & 0.333 & 0.667 \\
Pelaku Usaha/Entepreneur & 0.250 & 0.750 \\
Masyarakat/Community & & 0.250 \\
Sosial/Social & 0.750 & 0.750 \\
Pemerintah/Government & 0.250 & 0.750 \\
Pelaku Usaha/Entepreneur & 0.250 & 0.200 \\
Masyarakat/Community & & 0.250 \\
Kebijakan/Policy & 0.800 & 0.667 \\
Pemerintah/Government & 0.750 & 0.250 \\
Pelaku Usaha/Entepreneur & 0.333 & 0.750 \\
Masyarakat/Community & & 0.750 \\
Sumber Daya/Resources & 0.750 & \\
Pemerintah/Government & 0.250 & \\
Pelaku Usaha/Entepreneur & 0.250 & \\
Masyarakat/Community & &
\end{tabular}

Sumber : Data primer diolah, 2019/Source : Primary Data Processed, 2019 
Perikanan dan juga beberapa instansi terkait lainnya. Hal tersebut sesuai dengan hasil yang ditampilkan pada tabel diatas dimana terlihat dari semua indikator pengukur bobot nilai pemerintah lebih tinggi dibandingkan dengan pelaku usaha dan masyarakat. Nilai tersebut menunjukkan pemerintah yang paling berkepentingan untuk melakukan tindakan teknis terkait cara menurunkan volume impor salmon.

Tujuan kedua yaitu mencari dan meningkatkan produksi ikan yang bisa mensubtitusi ikan salmon merupakan tanggung jawab atau kepentingan dari pelaku usaha dan masyarakat. Pentingnya peran aktif pelaku usaha yang berbahan baku salmon ini dalam inovasi mencari ikan yang bisa menggantikan salmon sangat berpengaruh pada naik turunnya volume impor yang ada saat ini. Termasuk di dalamnya peran aktif dari masyarakat selaku konsumen akhir dari ikan-ikan salmon tersebut untuk bisa mencoba jenis-jenis ikan lainnya bukan hanya salmon.

\section{Tingkat Peranan Strategi dalam Pengendalian Impor Salmon-Trout}

Pengolahan pada level strategi menunjukan tingkat pengaruh strategi terhadap tujuan utama. Hasil dari pengolahan level strategi dapat dilihat pada Tabel 5 .

Berdasarkan Tabel 5 terlihat tiga dari empat faktor yang diidentifikasi distribusi pembobotan nilai terpusat di alternatif pertama sementara menurut faktor sosial, strategi lebih dulu dengan pendekatan pada masyarakat. Sedangkan mayoritas responden memilih alternatif pertama karena didasarkan pada kondisi saat ini dimana belum adanya ikan jenis lain yang dapat mensubstitusi permintaan terhadap ikan salmontrout.

Pengolahan pada level strategi menunjukkan tingkat pengaruh strategi terhadap strategi pengendalian impor ikan salmon-trout. Berikut hasil pengolahan vertikal pada level strategi dapat dilihat pada Tabel 6. Strategi yang dapat dilakukan untuk mengendalikan impor ikan salmon-trout diantaranya sosialisasi dan edukasi kepada masyarakat terkait jenis ikan yang memiliki kandungan gizi sama dengan salmontrout $(0,413)$, peningkatan ketersediaan dan perbaikan kualitas ikan lokal yang potensial untuk mensubtitusi ikan salmon-trout $(0,363)$, dan mengikuti kerjasama perdagangan internasional untuk membantu perluasan pasar ekspor $(0,224)$.

\section{STRATEGI PENGENDALIAN IMPOR IKAN SALMON-TROUT}

Berdasarkan hasil pengolahan data dengan metode penelitian analysis hierarchi process (AHP) maka diperoleh hasil berupa sub sektor yang harus menjadi prioritas untuk diperhatikan dan ditindaklanjuti serta pilihan strategi yang bisa diterapkan oleh pengambil kebijakan dalam hal ini pemerintah dan pelaku usaha baik pedagang/pemasar yaitu, pengolah perikanan dan masyarakat umum. Dukungan kebijakan menjadi prioritas utama yang harus segera ditindaklanjuti

Tabel 5. Pengolahan Bobot Nilai Tingkat Strategi dalam Pengendalian Impor Salmon-Trout. Table 5. Processing Value Weight of Strategie Level in Salmon-Trour Import Control.

\begin{tabular}{llccc}
\hline \multirow{2}{*}{ No } & Faktor/Factors & \multicolumn{2}{c}{ Alternatif Kebijakan/Policy Alternatives } \\
\cline { 3 - 5 } & & $\begin{array}{c}\text { Alternatif 1/ } \\
\text { Alternative 1 }\end{array}$ & $\begin{array}{c}\text { Alternatif 2/ } \\
\text { Alternative 2 }\end{array}$ & $\begin{array}{c}\text { Alternatif 3/ } \\
\text { Alternative 3 }\end{array}$ \\
\hline 1 & Ekonomi/Economy & 0.347 & 0.340 & 0.313 \\
2 & Kebijakan/Policy & 0.490 & 0.352 & 0.159 \\
3 & Sumber Daya/Resources & 0.468 & 0.363 & 0.169 \\
4 & Sosial/ Social & 0.346 & 0.438 & 0.215 \\
\hline
\end{tabular}

Keterangan/Remarks: Alternatif 1/ Alternative 1

Alternatif 2 / Alternative 2

Alternatif 3 / Alternative 3
Sosialisasi dan edukasi kepada masyarakat tentang jenis ikan yang memiliki kandungan gizi sama dengan salmon-trout/Dissemination and education to the public about fish species that have the same nutritional content as salmon-trout

: Peningkatan ketersediaan dan perbaikan kualitas ikan lokal yang potensial mensubstitusi Salmon-Trout/ Increased availability and improvement of quality of local fish that has the potential to substitute salmon-trout

Mengikuti kerjasama perdagangan internasional untuk ekspansi pasar ekspor/Following international trade cooperation to expand export market 
Tabel 6. Bobot dan Prioritas Alternatif Strategi dalam Pengendalian Impor Salmon-Trout. Table 6. Weight and Priority Alternative Strategies in Salmon-Trout Import Control.

\begin{tabular}{llcc}
\hline No & \multicolumn{1}{c}{$\begin{array}{c}\text { Alternatif Strategi/ } \\
\text { Strategy Alternatives }\end{array}$} & $\begin{array}{c}\text { Bobot Nilai/ } \\
\text { Weight Value }\end{array}$ & $\begin{array}{c}\text { Prioritas/ } \\
\text { Priority }\end{array}$ \\
\hline $\mathbf{1} \quad \begin{array}{l}\text { Sosialisasi dan edukasi kepada masyarakat tentang jenis ikan } \\
\text { yang memiliki kandungan gizi sama dengan Salmon-Trout/ } \\
\text { Dissemination and education to the public about fish species that } \\
\text { have the same nutritional content as Salmon-Trout }\end{array}$ & 0.413 & 1 \\
$\mathbf{2} \quad \begin{array}{l}\text { Peningkatan ketersediaan dan perbaikan kualitas ikan lokal } \\
\text { yang potensial mensubstitusi Salmon-Trout/Increased availability } \\
\text { and improvement of quality of local fish that has the potential to } \\
\text { substitute Salmon-Trout }\end{array}$ & 0.363 & 2 \\
$\mathbf{3} \begin{array}{l}\text { Mengikuti kerjasama perdagangan internasional untuk ekspansi } \\
\text { pasar ekspor// Following international trade cooperation to } \\
\text { expand export market }\end{array}$ & 0.224 \\
\hline Rasio Inkonsistensi /Inconsistency Ratio (RI) $=\mathbf{0 , 0 3}$ & \\
\hline
\end{tabular}

permasalahannya dan cepat ditemukan solusinya. Kebijakan disini maksudnya adalah bagaimana langkah pemerintah menghadapi situasi dimana tidak adanya salmon-trout di perairan Indonesia dan belum ada ikan lokal yang bisa mensubtitusikan keberadaan ikan Salmon-Trout.

Hasil analisis menunjukkan bahwa alternatif strategi pengendalian impor salmon-trout adalah dengan sosialisasi dan edukasi kepada masyarakat tentang jenis ikan lokal yang memiliki kandungan gizi seperti salmon-trout. Peruntukan impor salmon-trout lebih dari $75 \%$ digunakan untuk hotel, restoran, katering dan pasar modern dalam memenuhi permintaan ikan salmon-trout masyarakat. Pesatnya pertumbuhan kuliner terutama restoran masakan Jepang di Indonesia turut mendukung peningkatan impor komoditas ini. salmon-trout selama ini dianggap memiliki kandungan protein dan dagingnya mengandung minyak dengan kandungan lemak omega 3 dan omega 6 yang bermanfaat untuk fungsi otak dan penglihatan (Sulaksono, 2015). Tekstur dan warna daging salmon juga menarik berwarna orange kemerahan sehingga dianggap makanan yang cukup mewah untuk dikonsumsi masyarakat. Oleh karena itu strategi yang dianggap paling prioritas adalah sosialisasi dan edukasi terhadap masyarakat untuk meningkatkan pemahaman gizi tentang ikan lokal yang tidak kalah dari SalmonTrout. Berdasarkan Harsono (2018) dalam liputan6. com menjelaskan bahwa dari segi gizi ikan kembung ternyata punya gizi lebih tinggi daripada ikan Salmon, yang dibuktikan dengan kandungan protein, omega-3, vitamin B12, vitamin D, fosfor, vitamin B2, vitamin B6, iodine dan selenium yang lebih tinggi. Selain itu ikan lain yang terdapat di perairan Indonesia yang berpotensi mensubtitusi ikan salmon-trout adalah ikan tuna, dari segi tekstur dan citarasa tuna dianggap dapat menggantikan ikan salmon-trout akan tetapi ketersediaan ikan tuna di Indonesia juga tidak memiliki pasokan yang kontinu, sebagian besar tuna diekspor dan untuk memenuhi kebutuhan industri pengalengan. Jenis ikan lokal lain yang berpotensi menggantikan ikan salmon adalah patin, kebiasaan makan ikan salmon di Amerika dan Eropa sebagai salah satu menu mulai berubah dikarenakan harga yang lebih murah, kualitas yang baik serta tersedia setiap saat (Suryaningrum, 2008).

Strategi berikutnya yang dapat dilaksanakan untuk mengendalikan impor salmon-trout adalah peningkatan ketersediaan dan perbaikan kualitas ikan lokal yang potensial mensubstitusi salmontrout, bentuk peningkatan ketersediaan ini dapat dengan penambahan armada penangkapan maupun pengaturan sistem distribusi dan logistik serta perbaikan fasilitas dan pemahaman akan handling ikan sehingga ikan yang dihasilkan lebih banyak dan lebih berkualitas. Strategi ketiga yang ditawarkan adalah dengan mengikuti kerjasama perdagangan internasional untuk ekspansi pasar ekspor khususnya untuk meningkatkan produksi fillet salmon yang diekspor dari Indonesia. Kondisi saat ini karakteristik industri pengekspor salmon-trout hanya merupakan penyedia jasa proses (fee-processing) fillet samon-trout dimana supplier bahan baku telah ditentukan oleh buyer di luar negeri untuk kemudian diekspor kembali. Kerjasama internasional sangat penting sehingga kedepannya dapat berekspansi pasar, untuk memperluas pemasaran fillet ikan Salmon-Trout, sehingga ekspor dapat ditingkatkan dan devisa juga bertambah. 


\section{SINTESA KEBIJAKAN}

Kebijakan pengendalian impor Salmon-Trout merupakan bentuk "intervensi pemerintah" yang secara sengaja untuk mengatur masuknya produk impor serta melindungi aktivitas ekonomi dalam negeri. Kebijakan pengendalian impor SalmonTrout meliputi peningkatan daya saing produk domestik, perbaikan tata niaga dan perluasan pasar re-ekspor Salmon-Trout. Peningkatan daya saing produk domestik penting untuk dilakukan untuk melindungi pemanfaatan komoditas ikan lokal yang memiliki gizi setara dengan Salmon-Trout sehingga berbagai kegiatan sosialisasi, edukasi, maupun diversifikasi produk olahan berbahan ikan lokal perlu dilakukan. Peningkatan daya saing produk juga memerlukan keberpihakan kebijakan pemerintah yang menggairahkan iklim usaha seperti insentif fiskal yang cukup mendorong sektor usaha berekspansi dan menyiapkan persaingan di jangka panjang seperti penguasaan teknolog. iPerbaikan tata niaga perlu dilakukan diantaranya perbaikan dan pengembangan infrastruktur serta pengaturan logistik untuk menjamin ketersediaan ikan lokal yang berkualitas. Pengendalian impor dalam kaitan dengan kebijakan fiskal yang perlu menjadi pertimbangan adalah pengenaan tarif bea masuk pada produk-produk, perlunya harmonisasi tarif untuk produk-produk hilir dan hulu, serta pengaturan kuota impor. Pengaturan kuota impor harus didasarkan pada asas transparansi siapa yang dapat melakukan impor Salmon-Trout. Peninjauan kembali terkait mekanisme pemberian rekomendasi, izin dan pengawasan impor perlu dilakukan sehingga dapat disusun indikator yang jelas dalam penentuan besarnya rekomendasi impor yan diberikan, kewenangan pengawasan peruntukan bahan baku dan bahan penolong industri. Berbagai Kebijakan ini diharapkan akan tetap dapat memenuhi kebutuhan konsumen terbatas namun disisi lain peningkatan konsumsi komoditas ikan lokal yang berkualitas dapat terpenuhi.

\section{IMPLIKASI KEBIJAKAN}

Kebijakan pengendalian impor salmontrout untuk pemenuhan hotel, restoran, catering dan pasar modern harus mendukung optimalisasi pemanfaatan sumber daya perikanan dari perairan Indonesia secara optimal. Peningkatan konsumsi jenis ikan lokal yang memiliki kandungan gizi seperti salmon-trout penting untuk dilakukan melalui sosialisasi dan edukasi kepada masyarakat. Jaminan ketersediaan dan kualitas ikan lokal yang potensial mensubstitusi salmontrout harus disiapkan melalui pengaturan sistem distribusi dan logistik serta perbaikan fasilitas dan penanganan ikan sesuai kebutuhan pelaku usaha maupun masyarakat. Di sisi lain, impor salmon-trout yang diolah untuk kemudian diekspor kembali ke luar negeri harus ditingkatkan. Peningkatan impor salmon trout akan memberikan keuntungan bagi peningkatan devisa negara sehingga tidak perlu dibatasi dengan kuota. Dukungan kebijakan pendukung yang diperlukan diantaranya kemudahan proses perizinan impor untuk kegiatan re-ekspor dan perluasan pasar internasional (ekspansi) melalui kerjasama internasional.

\section{UCAPAN TERIMA KASIH}

Terima kasih penulis ucapkan kepada Freshty Yulia Arthatiani selaku ketua tim peneliti yang banyak memberikan bimbingan dan masukan selama penulisan. Selain itu kami ucapkan kepada Direktorat Logistik, Direktorat Pengolahan dan Bina Mutu serta Badan Karantina Ikan dan Pengendalian Mutu, Kementerian Kelautan dan Perikanan yang banyak membantu dalam penyediaan data bagi penelitian ini dan khususnya kepada Balai Besar Riset Sosial Ekonomi Kelautan dan Perikanan yang telah memfasilitasi pelaksanaan kegiatan penelitian untuk menghasilkan karya tulis ilmiah ini.

\section{PERNYATAAN KONTRIBUSI PENULIS}

Kontributor dalam karya tulis ilmiah adalah Tenny Apriliani sebagai kontributor utama dan Rismutia Hayu Deswati sebagai kontributor anggota yang sudah disepakati bersamasama untuk diketahui semua pihak yang berkepentingan.

\section{DAFTAR PUSTAKA}

Arthatiani, F. Y., \& Deswati, R.H. (2020). Strategi Pengendalian Impor Mckarel Sebagai Bahan Baku Usaha Pemindangan. Jurnal Kebijakan Sosial Ekonomi Kelautan dan Perikanan Volume 10 No.1: 39-52. DOI: http://dx.doi.org/10.15578/ jksekp.v10i1.8622.

Asche, F., Dahl, R.E., Gordon, D.V., Trollvik, T., \& Aandahl, P. (2011). Demand Growth for Atlantic Salmon: The EU and Frech Markets. Marine Resource Economics, Volume 26, pp. 255-265. URL: http:// www.bioone.org/doi/full/10.5950/0738-136026.4.255. 
[BPS]. Badan Pusat Statistik. (2019). Statistik Ekspor Impor Tahun 2012-2019. Jakarta.

Efendi, R. (2009). Faktor-Faktor Penentu Impor Minyak Bumi di Indonesia. Jurnal Ekonomi dan Bisnis Vol. 8, No. 3: : $247-257$.

Elvestad, C. (2009). Improving Market Access for Salmon Through Free Trade Agreements: The Role of Interests and Institutional Frameworks. Marine Policy (33) : 606-612. doi:10.1016/j. marpol.2008.12.004.

FAO. (2015). Globefish Highlights-A Quarterly Update on World Seafood Markets 37-42. Retrieved From: https://www.nature.com/articles/s41538018-0025-5.pdf.

Ghodsypour, S.H. \& O'Brien, C. (1998). A decision support system for supplier selection using an integrated analytic hierarchy process and linear programming. International Journal of Production Economics Volumes 56-57: 199-212.https://doi.org/10.1016/S0925-5273(97) 00009-1.

Harsono, F. H. (2018). Ikan Kembung Justru Lebih Kaya Gizi Ketimbang Salmon. Retrieved From: https://www.liputan6.com/health/read/3667512/ ikan-kembung-justru-lebih-kaya-gizi-ketimbang-salmon.

Helander, E. H. (2017). International Marketing: Reentering the Chinese Salmon Market: Case Study of Leroy Seafood ASA. Retrieved From: http://hdl.handle.net/10071/15837.

Imam, A. (2013). Faktor-faktor yang Mempengaruhi Impor Barang Konsumsi di Indonesia. Jurnal Kajian Ekonomi dan Pembangunan Vol 1 no.02: DOI: http://dx.doi.org/10.24036/ jkep.v1i02.121.

Indramadhini, L., \& Sitompul, P. (2015). Pengaruh Kausalitas Ekspor, Impor dan GDP di Indonesia. Media Ekonomi 23 (1): 11-26.

Krugman, P. R., \& Maurice, O. (2000). Ekonomi Internasional Teori dan Kebijakan. Edisi Kelima. Jilid 2. Jakarta: PT. Indeks Kelompok Gramedia.

Laucereno, S.F. (2019). BPS : Konsumsi Makanan dan Minuman Tumbuh Melambat. Retrieved From:(https://finance.detik.com/beritaekonomi-bisnis/d-4415759/bps-konsumsi-makanan-dan-minuman-tumbuh-melambat, 2019).

Mankiw, N.G. (2013). Pengantar Ekonomi Makro. Jakarta: Salemba Empat.

Pakpahan, A. (2012). Analisis Faktor-Faktor Yang Mempengaruhi Impor Daging Sapi Di Indonesia. Economics Development Analysis Journal 1(2): 1-9. https://doi.org/10.15294/edaj. v1i2.471.
Peraturan Pemerintah No 9 Tahun 2018 Tentang Tata Cara Pengendalian Impor Komoditas Perikanan Dan Komoditas Pergaraman Sebagai Bahan Baku Dan Bahan Penolong Industri.

Peraturan Menteri Kelautan dan Perikanan Republik Indonesia Nomor 58 Tahun 2018 Rekomendasi Pemasukan Hasil Perikanan Selain Sebagai Bahan Baku dan Bahan Penolong Industri.

Putri, A. (2017). Faktor-Faktor Yang Mempengaruhi Impor Kedelai Di Indonesia Tahun 1981-2011. Economics Development Analysis Journal 4(2), 98-105. Https://Doi.Org/10.15294/ Edaj.V4i2.14809.

Rostin, Nusanta, A.W., Rafiy, M., Rumbia, R., Putera, A. \& Saranani, F. (2018). Analytic Hierarchy Process Method In Arranging Grand Design Of Food Estate In The Development Of Fishing Industry In Southeast Sulawesi. Journal of Economics and Finance (IOSR-JEF) 9(4): 69-74. DOI: 10.9790/59330904036974.

Sari, E.T. (2006). Peranan Customer Value Dalam Mempertahankan Keunggulan Bersaing Pada Restoran Cepat Saji. Jurnal Manajemen Perhotelan, Vol. 2, No. 2: 68-75. http://puslit2. petra.ac.id/ejournal/index.php/hot/article/ viewFile/16512/16504

Setälä, J., Saarni, K. \& Honkanen, A. (2001) The Quality Perceptions of Rainbow Trout Defined by different Fish Market Sectors. In: Microbehavior and Macroresults. Proceedings of the Tenth Biennial Conference of the International Institute of Fisheries Economics and Trade, July 10-14, 2000, Corvallis, Oregon, USA. International Institute of Fisheries Economics and Trade (IIFET). Retrieved from: https://ir.library.oregonstate.edu/concern/ conference_proceedings_or_journals/ r207tq32m.

Siswanto, E., Sinaga, B. M., \& Harianto. (2018). Dampak Kebijakan Perberasan pada Pasar Beras dan Kesejahteraan Produsen dan Konsumen Beras. Jurnal IImu Pertanian Indonesia. Vol 23(2): 93-100. doi: 10.18343/jipi.23.2.93.

Sulaksono, S. (2015). Manfaat EPA dan DHA bagi pertumbuhan Anak dan Balita. Retrieved from: https://carakhasiatmanfaat.com.

Sukirno, S. (2000). Makro Ekonomi Moderen:Perkembangan Pemikiran Dari Klasik Hingae Keynesian Baru. Jakarta: PT Raja Grafindo Persada.

Tyagi, Rajesh; Das, Chandrasekhar. (1977). A methodology for cost versus service trade-offs in wholesale location-distribution using mathematical programming and analytic hierarchy process. Journal of Business Logistics; Hoboke 
n Vol. 18, Iss. 2, (1997): 77-99. Retrieved from: https://search.proquest.com/openview/67baafdaa9d208566acf5932f8196993/1?pq-origsite=gscholar\&cbl=36584.

Suryaningrum, T.D. (2008). Ikan Patin : Peluang Ekspor, Penanganan Pascapanen dan Diversifikasi Produk Olahannya. Squalen Vol 3 No.1: 16-23. Retrieved from: https://bbp4b.litbang.kkp.go.id/ squalen-bulletin/index.php/squalen/article/ view/166/123

Varina, F. (2018). Dampak Tarif Impor Jagung terhadap Kesejahteraan Pelaku Pasar Jagung Indonesia. Jurnal Agrosains dan Teknologi Vol 3 (1): 47-64.

Xie, J., Kinnucan, H.W., \& Myrland, O. (2009). Demand elasticities for farmed salmon in world trade. European Review of Agricultural Economics, Volume 36, Issue 3, September 2009, Pages 425-445, https://doi.org/10.1093/erae/jbp028. 